Available online at GSC Online Press Directory

GSC Biological and Pharmaceutical Sciences

e-ISSN: 2581-3250, CODEN (USA): GBPSC2

Journal homepage: https://www.gsconlinepress.com/journals/gscbps

(RESEARCH ARTICLE)

\title{
Distribution of freshwater Mollusca in Koothaippar wetland ecosystem Tiruchirappalli District Tamil Nadu
}

\author{
R. Ranjani ${ }^{1}$ and A. S. Maheswari ${ }^{2, *}$ \\ ${ }^{1}$ Research Dept. of Zoology, Seethalakshmi Ramaswami College, Affiliated to Bharathidasan University, Tiruchirappalli-2. \\ ${ }^{2}$ Assistant Professor and Head, Research Dept. of Zoology, Seethalakshmi Ramaswami College, Affiliated to \\ Bharathidasan University, Tiruchirappalli-2.
}

Publication history: Received on 11 October 2020; revised on 29 October 2020; accepted on 02 November 2020

Article DOI: https://doi.org/10.30574/gscbps.2020.13.2.0341

\begin{abstract}
Freshwater Mollusca form an important animal group of the wetland ecosystems. The distribution and availability in terms of number of species needs scientific attention. Present study is an attempt to document the available Molluscan forms in Koothaippar wetlands of Tiruchirappalli District. This study was carried out between summer 2013 to postmonsoon 2017. Nine species were recorded and among them 6 species belong to Gastropoda representing 2 orders, 3 families, 3 genera while 3 species were bivalves representing 1 order, 1 family and 2 genera. Bellamya bengalensis, Lamellidens marginalis and Pila globosa were the predominantly present molluscan fauna and are distributed throughout the year. Five species of Molluscan fauna (Pila virens, Pila scutata, Bellamya dissimilis, Indoplanorbis exustus and Lamellidens corrianus) are less abundant and Parreysia favidens was found to be rare species of the ecosystem. These Molluscan forms, representing different families ranging from 34\% of Ampullariidae, 33\% of Unionoida, 22\% of Viviparoidae and 11\% of Planorbidae. Percent distribution of these shelled organisms indicate that they represent 3 orders viz., $56 \%$ of Architaenioglossa, 33\% of Unionoida and 11\% of Hygrophila.
\end{abstract}

Keywords: Checklist; Distribution; Freshwater Molluscan; Koothaippar wetland

\section{Introduction}

Global freshwater is the most precious human resource covering about 75\% of the globe, but most of the water is saline. Less than $5 \%$ of water is fresh and much of this water is in the ice caps, glaciers and groundwater. Most of the remainder is in lakes, streams and soil moisture. All life depends on water and exists in nature in many forms like ocean, river, lake, cloud, rain, snow and fog. Lakes, one of the wetlands are highly complex water, land interactive system, and the most fertile productive ecosystems in the world. Aquatic ecosystem provides habitat for many varieties of life forms such as phytoplankton, zooplankton, aquatic plants, insects and Molluscan fauna. India has a total of 27, 403 wetlands of which 23,444 are inland with major river systems. Wetlands are one of the most productive ecosystems in the world which are natural or artificial, permanent or temporary water bodies with water that is static or running (Hilton and Phillips, 1982; Wetzel, 2001; Tuzen et al., 2002; Sulekh Chandra, et al., 2012; Parameswara Naik, 2012 and Rajakumar, 2012). Molluscan forms are one of the most threatened major taxonomic groups worldwide, comprising $42 \%$ and they are taxonomically classified into 7 classes, namely Aplacophora, Polyplacophora, Monoplacophora, Gastropoda, Bivalvia, Scaphopoda and Cephalopoda in diverse habitats and is generally categorized into freshwater, marine and terrestrial forms.

\footnotetext{
${ }^{*}$ Corresponding author: A. S. Maheswari

Assistant Professor \& Head, Research Dept. of Zoology, Seethalakshmi Ramaswami College, Affiliated to Bharathidasan University, Tiruchirappalli-2.
}

Copyright (C) 2020 Author(s) retain the copyright of this article. This article is published under the terms of the Creative Commons Attribution Liscense 4.0. 
Freshwater Molluscan play an essential role in the maintenance of wetland ecosystems due to their action on water quality and nutrient balance by their filtration activity and algae-grazing and they are the major food source for several fish species, birds, and other animals. They play a significant role in aquatic ecosystems and species like Bellamya bengalensis, Pila virens and Lamellidens marginalis are proven food species for many of the aquatic animals and human beings. Besides, Lamellidens marginalis and Lamellidens corrianus have also been used to produce pearls in some parts of India. Out of the seven classes of Molluscan forms, Gastropoda is the largest and most diverse class comprising 65000 to 75000 species including marine, freshwater and terrestrial forms many of which are important to man. They feed on algae, zooplankton and organic wastes and provide food for many types of fishes, birds and human beings. They play an important role in the freshwater ecosystem by providing food for many animals and by grazing on vast amounts of algae and detritus matter (Subba Rao and Dey, 1989; Vaught, 1989; Tulp et al., 2010; Dillon, 2000; Agudo Padron, 2011 and Szabo and Amesbury, 2011 and Tacon and Metian, 2013). Koothaippar wetland is one such unique natural wetland ecosystem known for its agricultural and socio-economic importance, distributed in about $16 \mathrm{~km}$ length and $6 \mathrm{~km}$ width in the Tiruchirappalli District. There are 8 outlets in both the regions of the lake through which more than 25,000 acres of agricultural fields are getting irrigated. It provides a good natural habitat and an excellent feeding (foraging) ground for many waterbirds. This study is designed with the following objectives to fulfill the lacuna.

To survey, identify and to make a checklist of the available Molluscan forms

Classification of the species into families and orders.

\section{Material and methods}

\subsection{Study area}

Koothaippar Lake is situated $15 \mathrm{~km}$ South of Tiruchirappalli District (1047'50"N; 7846'16"'E), Tamil Nadu, South India (Fig.1.). There are many small villages and towns on all sides of the lake which are dependent for their agricultural and domestic use. There are eight outlets in the lake through which more than twenty-five thousand acres of fields are getting irrigated. The lake is under the control of the Public Works Department. It offers a wide variety of microhabitats that provides suitable substrates for water birds. This lake is an attraction for many migratory birds such as Cormorants, Indian Darter, Asian Openbill Stork, White Ibis, Spotbill Duck and Pintail Duck. Besides, it also supports an enriched distribution of freshwater Molluscan forms. The Koothaippar lake and its watershed regions are situated in the rain shadow regions for southwest monsoon (June - August) and receive northeast monsoon (September - December) only. The climate is subtropical. Hot weather prevails from March to June, and the maximum temperature varies from $38{ }^{\circ} \mathrm{C}$ to $40{ }^{\circ} \mathrm{C}$.

\subsubsection{Regions of the lake}

Based on the depth contour, distribution of aquatic vegetation (which plays a major role in the faunal distribution in the lake) and human disturbance, two regions [Region I (RI) and Region II (RII)] were demarcated in the lake artificially by imaginary boundaries for the present study.

\section{Region I}

This region is of open, shallow water and extends for about $5 \mathrm{~km}$. It is highly polluted by domestic sewage and characterized by thick aquatic vegetation and dominated by Ipomea aquatica, Cyperus sp. and Acacia sp. This is nearer to the inlet of the lake. Cattle grazing is a major disturbance in this region. (Fig 2).

\section{Region II}

This region is of open, deep water habitat extending for about $5 \mathrm{~km}$. On its western side patches of Cyperus sp. predominate. (Fig 2.1.).

\subsubsection{Study period}

The study was conducted and data were collected throughout the year from summer 2013 to post-monsoon 2017 to cover four seasons viz., pre-monsoon (August and September), monsoon (October - December), post-monsoon (January - March) and summer (April-July) consecutively for four years. 


\subsubsection{Freshwater Molluscan Studies}

Molluscan forms were collected from the bottom sediment using dredge (Peterson grab). In addition to this, they were also collected from the aquatic vegetation and from the floating objects. A scoop-net $(30 \mathrm{~cm} \times 30 \mathrm{~cm}$ frame of steel bars), wire netting, a scoop (10 cm deep with $8 \mathrm{~cm}$ wide blade soldered to the frame), and a wooden handle was used for the collection of Molluscan species on aquatic vegetation. The hand net or scoop net was dragged over the aquatic vegetation, and when it is filled with aquatic weeds, the contents were poured out on a spread - out cloth piece. Molluscan species were picked up with a pair of forceps from the weeds. While making the collections care is taken to use, boot and never with barefoot and hands and arms were repeatedly cleaned with 70\% ethanol if bare hands were used to collect the Molluscan forms.

\subsubsection{Fixation and preservation of Molluscan species}

Identification of Molluscan species was not entirely based on shell characters alone especially for the members of the family Lymnaeidae as it is difficult to identify them by shell characters alone. Morphological details like the structure of radula, shape of the prostate gland were also examined to arrive at an accurate identification of a species. For this purpose, the soft parts of the animals were preserved along with the shell. Molluscan forms collected were placed in an enamel tray with source water. Finely powdered menthol was sprinkled over the water surface and covered by a suitable lid. The specimens were left for 24 hours. After narcotization, the snails have preserved inn $70 \%$ ethyl alcohol.

\subsubsection{Preparation of dry shell}

After narcotization, the animal was extracted from the shell with a pair of curved forceps. Empty shells were boiled in water for about 30 minutes to an hour, to remove any soft tissues sticking inside the shell. The shells were further cleaned with a smooth brush and then dried in the air. In the case of operculate shells, operculum was retained by pasting it to the cotton wool plug inserted into the aperture of the shell. Dry shells were packed in the cotton wool in the small glass vials or the tubs or cardboard boxes depending upon the size of the shell. The packages were labelled with the relevant details such as place of collection, date and time of collection.

\subsubsection{Collection of Molluscan species}

Specimens were collected by handpicking method from dry parts of the regions, where water was shallow and hence scoop net was used. All the samples were transported to the laboratory in large plastic bottles. They were washed, counted, photographed, taxonomically identified and documented (Subba Rao, 1989). $1^{3}(1 \times 1 \times 1)$ foot, quadrates were laid at the study area and Molluscan samples were collected, separated and the dead and live were brought to the laboratory for further identification. Quadrates are small plots of uniform shape and size, placed randomly in selected foraging sites for sampling purposes. The number of quadrates laid was based on the size of the foraging ground. Molluscan shells were collected by handpicking, scraping method. The shells were washed with water to remove adhering debris without damaging and then dried. The collected Molluscan specimens were identified with morphological characters. The gastropods were mainly identified based on the spire length and shape, mouth opening, operculum, umbilicus, colour and ornamentation and bivalves on the nature of hinge, interlocking dentition, with referred to elsewhere Subba Rao (2011), Ramakrishna and Dey (2010), Venkatraman and Venkatraman (2012) respectively.

\subsubsection{Wet micro Molluscans}

Wet specimens for anatomical study may be stored in a variety of preservatives, whereas for molecular work strong (>95\%) ethanol or freezing in liquid nitrogen at $-190^{\circ} \mathrm{C}$ are the best preservatives. The particular fluid medium (e.g., water, ethanol, formalin, and gluteraldehyde) has little effect on the mechanics of the handling techniques. 


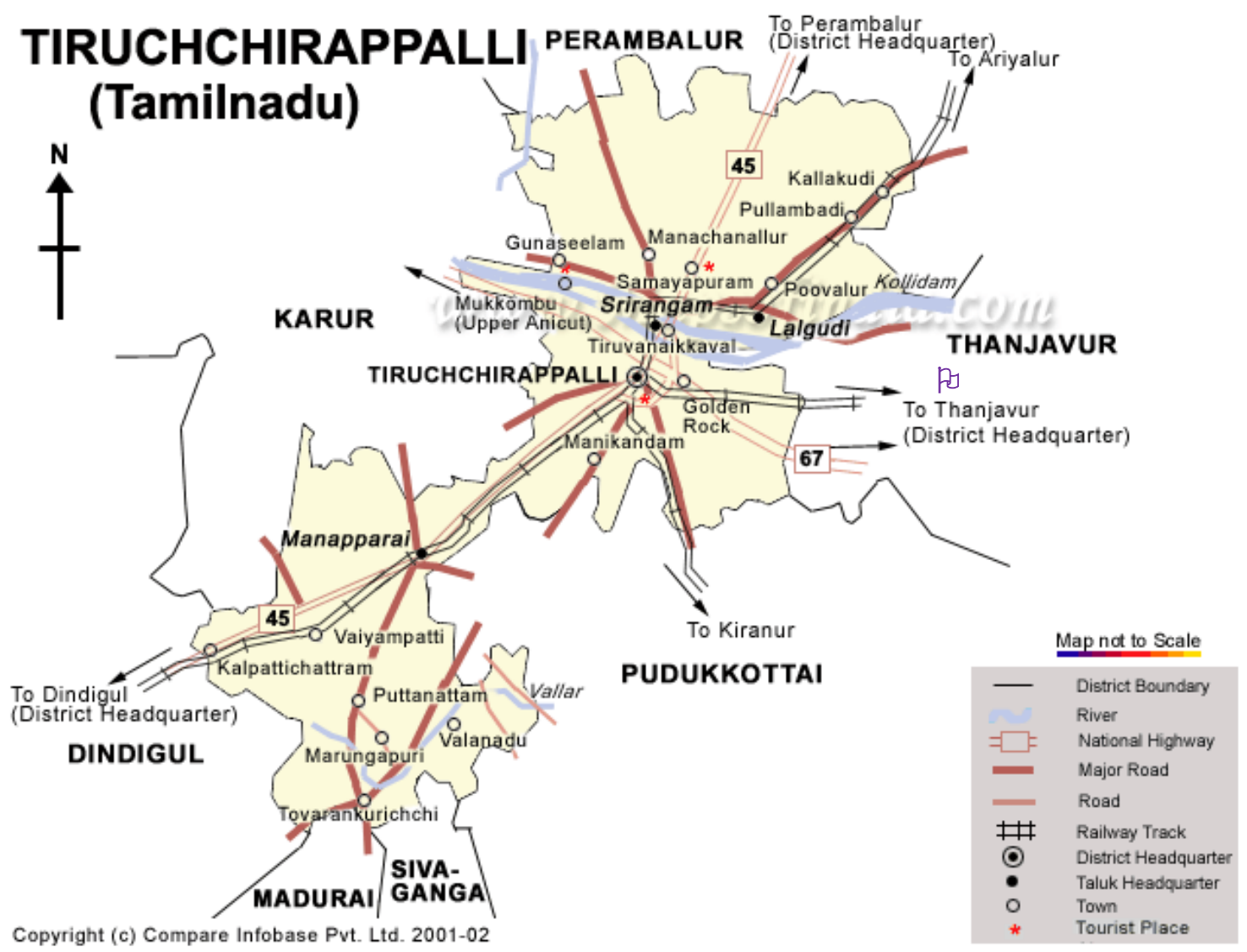

Figure 1 Study Area

Indicates the location of the Koothaippar Lake at Tiruchirappalli

\section{Results and discussion}

\subsection{Freshwater Molluscan forms}

Documentation of different species of freshwater Molluscan forms from two different regions of Koothaippar wetland ecosystems of Tiruchirappalli District was done to understand its distribution as the study on this particular aspect is scarce and wanted. Totally nine species of freshwater Molluscan forms were recorded during the study period (2013 Summer to 2017 Post-monsoon), covering four seasons (Summer- April, May, June), (Pre-monsoon-July, August, September), (Monsoon - October, November, December) and (Post-monsoon - January, February and March. Out of which six species from Gastropoda and three species from Bivalvia were documented (Fig. 3.).

These freshwater Molluscan forms were representing four families (Ampullariidae, Planorbidae, Unionidae and Vivipariidae) belonging to five genera (Bellamya, Indoplanorbis, Lamellidens, Pila and Parreysia). Percentage distribution (Family-wise) of freshwater Molluscan forms revealed that $34 \%$ are from Ampullariidae, $33 \%$ of Unionoidae, $22 \%$ of Viviparoidae and $11 \%$ of Planorbidae (Fig. 4.). Further the distribution of the orders of these Molluscan forms reveals that the distribution $56 \%$, representing the order Architaenioglossa, $33 \%$ of Unionoida and $11 \%$ of Hygrophila (Fig. 5.).

Identification of Molluscan species is carried out based on the size, shape, morphology, individual character and life history. 9 species of freshwater Molluscan forms were identified with the help of the standard identification manual (Subba Rao, 1989). Bellamya bengalensis, Lamellidens marginalis and Pila globosa were documented as the predominant species and are found to be present throughout the study period while the other five species of Molluscan forms Pila virens, Pila scutata, Bellamya bengalensis, Indoplanorbis exustus and Lamellidens corrianus were found to be less abundant and Parreysia favidens was classified as a rare species in this ecosystem. (Table.1.). Overall highest number of species was found during the summer season and lowest numbers were found during the winter season. 

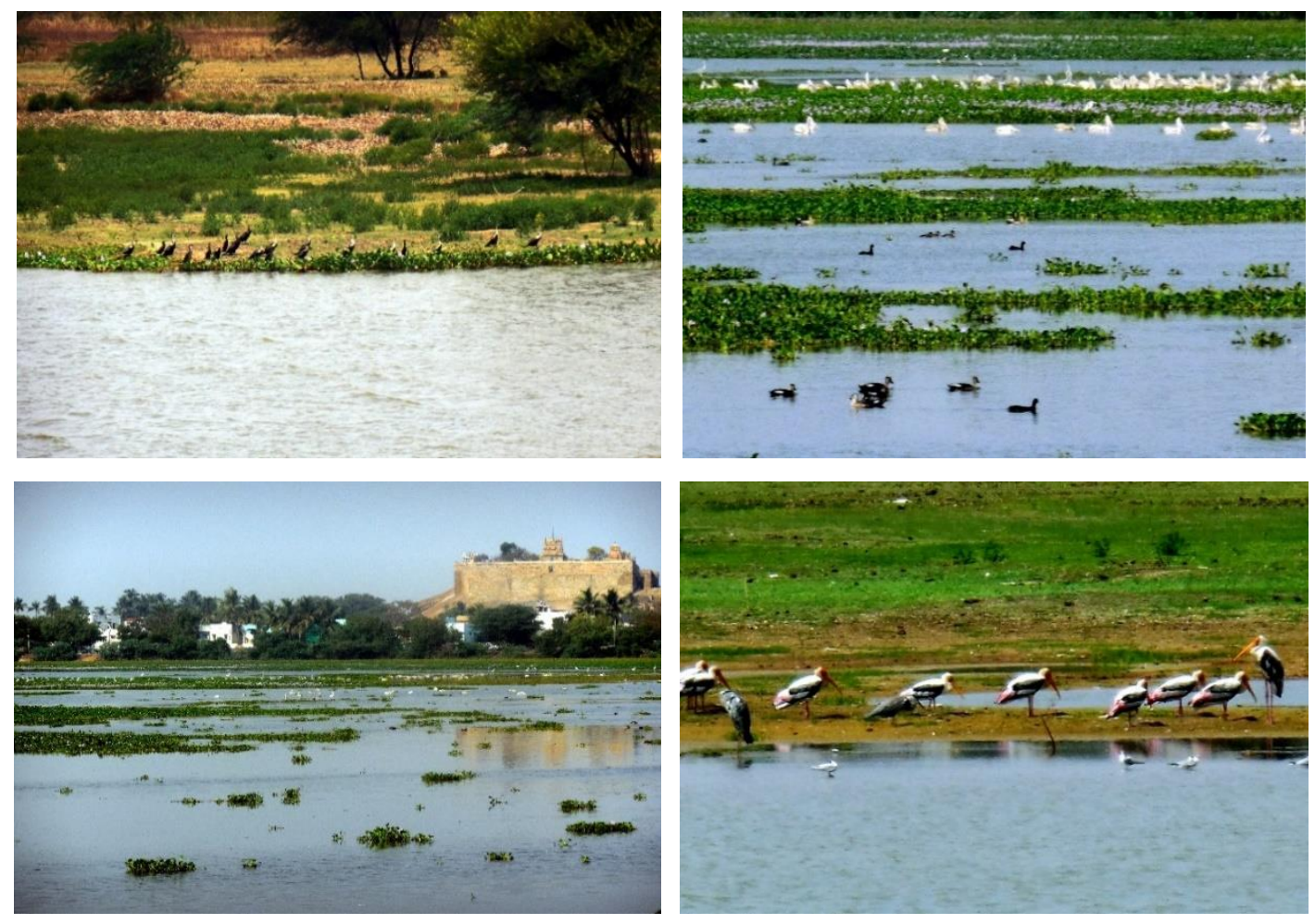

Figure 2 Views Of Study Area In Region I Koothaippar Wetland Ecosystem During The Study Period
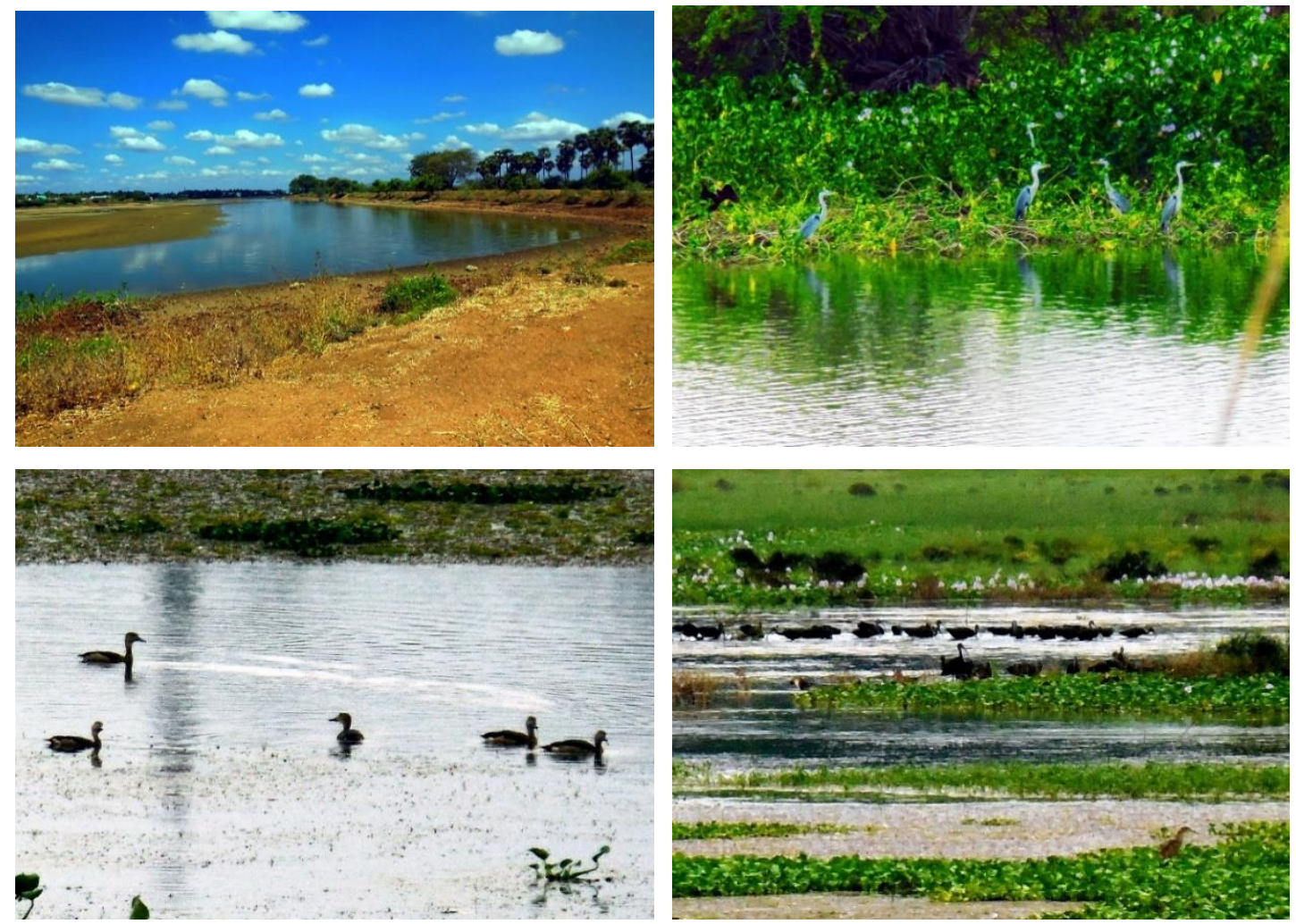

Figure 3 Views Of Study Area In Region II Koothaippar Wetland Ecosystem During The Study Period 


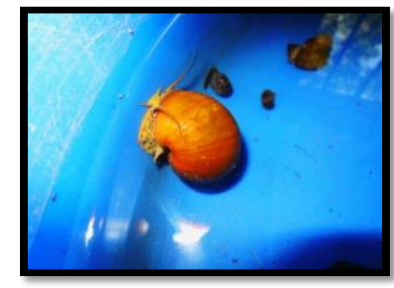

Pila globosa

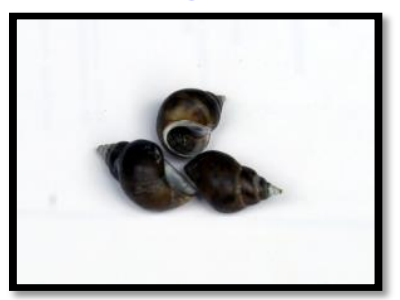

Bellamva bengalensis

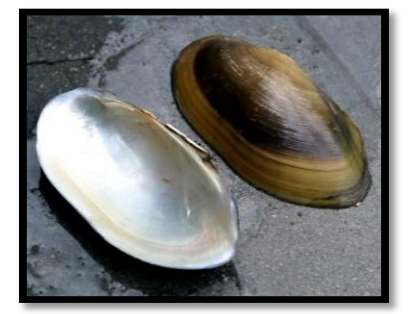

Lamellidens marginalis Lamellidens corrianus

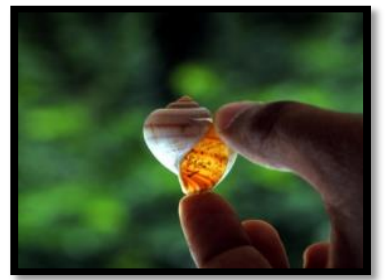

Pila virens

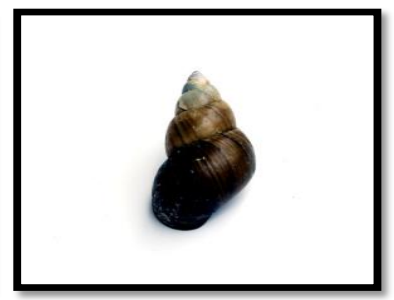

Bellamva dissimilis

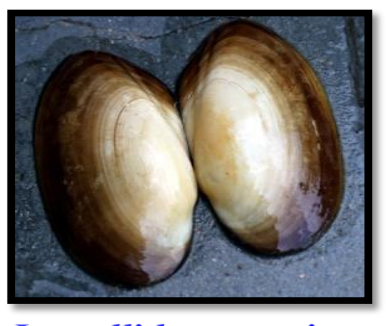

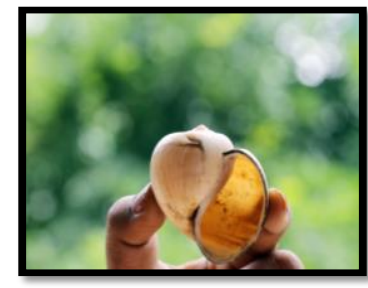

Pila scutata

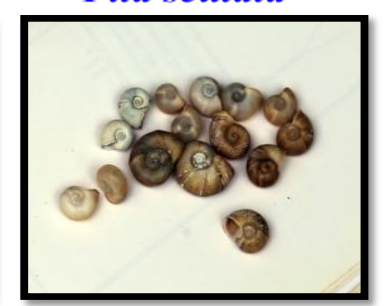

Indoplanorbis exustus

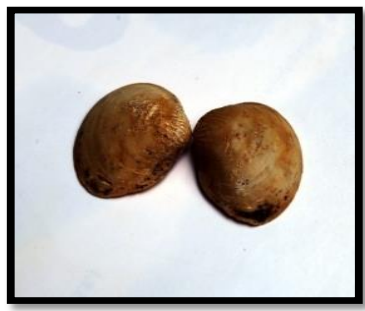

Parrevsia favidens

Figure 4 Check list of Freshwater Molluscan forms in Koothaippar wetland ecosystems Tiruchirappalli district

Table 1 Checklist Of Freshwater Molluscan Forms In Koothaippar Wetland Ecosystem

\begin{tabular}{|l|l|l|l|l|l|}
\hline S.No. & Class & Scientific Name & Family & Order & Status \\
\hline \multirow{4}{*}{1.} & \multirow{2}{*}{ GASTROPODA } & Pila globosa & Ampullariidae & Architaenioglossa & ++++ \\
\cline { 3 - 6 } & & Pila virens & Ampullariidae & Architaenioglossa & +++ \\
\cline { 3 - 6 } & & Pila scutata & Ampullariidae & Architaenioglossa & +++ \\
\cline { 3 - 6 } & & Bellamya bengalensis & Viviparoidae & Architaenioglossa & ++++ \\
\cline { 3 - 6 } & & Bellamya dissimilis & Viviparoidae & Architaenioglossa & ++ \\
\cline { 3 - 6 } & Indoplanorbis exustus & Planorbidae & Hygrophila & ++ \\
\hline 2. & \multirow{2}{*}{ BIVALVIA } & Lamellidens marginalis & Unionidae & Unionoida & ++++ \\
\cline { 3 - 6 } & & Lamellidens corrianus & Unionidae & Unionoida & +++ \\
\cline { 3 - 6 } & & Parreysia favidens & Unionidae & Unionoida & + \\
\hline
\end{tabular}

(++++Abundant; +++Less Abundant; ++ rare; + Very rare) 


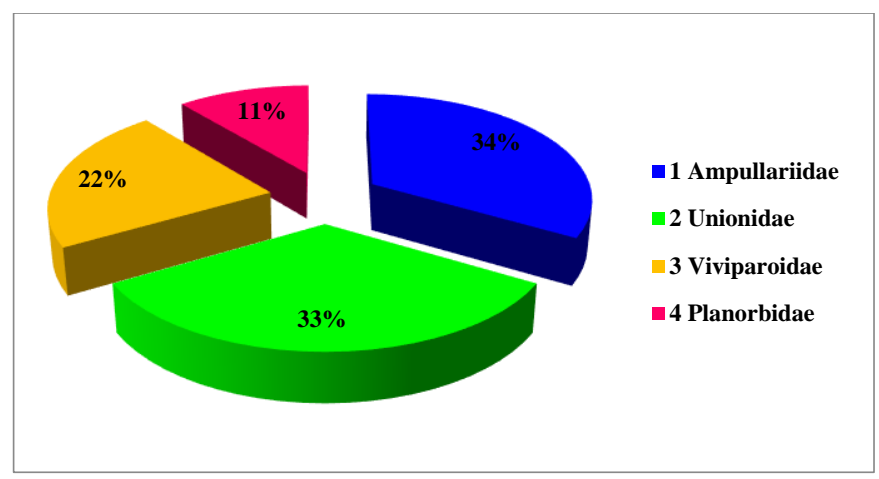

Figure 5 Pie chart representing the percent distribution of Molluscan forms of different families

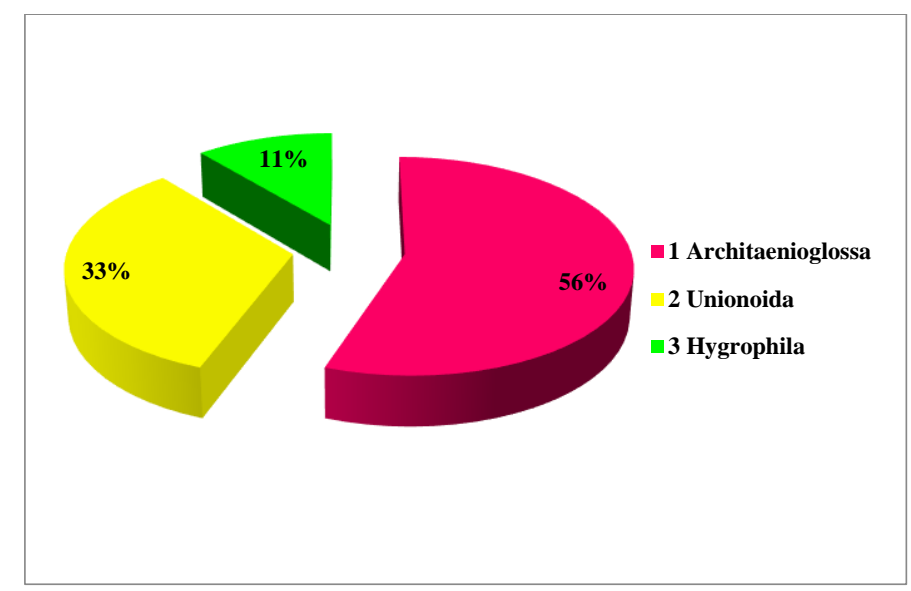

Figure 6 Pie chart representing the percent distribution of Molluscan forms of different orders

\section{Conclusion}

Total of nine freshwater Molluscan species representing 3 orders, 4 families and 5 genera were recorded during the study period. Distributions of these organisms are also greatly influenced by many environmental parameters which require detailed study further. This ecosystem supports a wide variety of fresh water Molluscan species both in terms of number in a species and diversity. A detailed study on their seasonal distribution and fluctuations would help in the documentation of many unknown species also.

\section{Compliance with ethical standards}

\section{Acknowledgments}

The authors are thankful to the University Grants Commission for the support of Grant under Major Research Project (Assessment of Molluscan prey community and its impact on the distribution of Asian Openbill storks in Koothaippar Wetland Ecosystem, Tiruchirappalli (UGC Letter No - F.No.42-628/2013 (SR) - 6.3.2013) to carry out this research. They are also thankful to the college management and the principal for the permission to utilize the facilities available in the institution for this study. I also thank the Bharathidasan University, for their support and permission to carry out this research work for Ph.D.

\section{Disclosure of conflict of interest}

We disclose that there is no conflict between us for the publication of this research article in your journal. 


\section{References}

[1] Agudo pardon, AI, Current knowledge on population studies on five continental Molluscan (Mollusca, Gastropoda, and Bivalvia) of Santa Catarina State (SC, Central Southern Brazil region), Biodiversity Journal, 2011; Vol. 2, no.1: pp 9-12.

[2] Dillon, RT, Jr. The Ecology of Freshwater Molluscs. Cambridge University Press, Cambridge, U.K. 509. 2000.

[3] Hilton, J and Philips, G L The effect of boat activity on turbidity in a shallow road land river. Journal of Applied Ecology, 1982; 19: pp 143-150.

[4] Parameswara Naik, TKV, Ajayan and Gangadharaiah Lokesh. Physico chemical characteristics of Kunigal Lake in Tumkur district, Karnataka, India; Int. J. Chem. Sci. 2012; 10(2): pp 655-663.

[5] Rajakumar, R. 2012 A Study On Aquatic Bird Diversity And Environmental Quality Of The Udhayamarthandapuram Bird Sanctuary, Thiruvarur District, Tamil Nadu, India, Ph.D thesis, Tamil University, Thanjavur, Tamil Nadu, India.

[6] Subba Rao, NV. Handbook freshwater Molluscs of India. Zoological survey of India. The Radiant process private Limited Calcutta. 1989; Pp 1-283.

[7] Subba Rao, NV and Dey, A. Freshwater Molluscs of Misoram. J. Hydrobiol. 1989; 2: pp 25-32.

[8] Subba Rao, NV, Dey, A. Freshwater Molluscs of India. Zoological Survey of India. Calcutta, 1989, Gupta, S.K. and Singh, J. 2011; pp 225- 232.

[9] Sulekh Chandra, Arendra singh and Praveen Kumar Tomar. Assessment of Water Quality Values in Porur Lake Chennai, Hussain Sagar Hyderabad and Vihar Lake Mumbai, India: Zakir Husain College (University of Delhi), J. L. N. Marg, New Delhi, India: Chem Sci Trans., 2012; 1(3): pp 508- 515.

[10] Szabo, K., and Amesbury, JR. Molluscs in a world of islands: The use of shellfish as a food resource in the tropical island Asia- Pacific region. Quarter national, 2011; pp 239-818.

[11] Tacon, A. G. J, and Metian, M. Fish Matters: Importance of Aquatic Foods in Human Nutrition and Global Food Supply. Reviews in Fisheries Science 2013; 21: pp 22-38.

[12] Tulp, I, J.A.M. Craeymeersch, M.F.Leopold, C.J.G.Van Damm, F.Fy-Hofstede, J.P. Verdaat. The role of the invasive bivalve Ensis directus as food source for fish and birds in the Dutch coastal Zone. Estuarine, Coastal and Shelf Science, 2010; 90: pp 116-128.

[13] Tuzen, M. Investigation of some physical and chemical parameters in the Lake Isykli in Denizli, Turkey. Fresen. Environ. Bull., 2002: 11: pp 202-207.

[14] Vaught, K C. A classification of the living Mollusca: American Malacological Incorporation, Melbourne. 1989.

[15] Venkatraman, C and Venkataraman, K. Diversity of Molluscan Fauna along the Chennai Coast, May 22 nd International day for Biological Diversity Marine Biodiversity, 2012; pp 29-35.

[16] Wetzel, RG. Limnology. Lake and river system. 3ed. Academic press. San Diego. 2001; Pp 1006. 